OnLine Journal of Biological Sciences 10 (2): 103-108, 2010

ISSN 1608-4217

(C) 2010 Science Publications

\title{
Temperature Optimization for Bioethanol Production from Corn Cobs Using Mixed Yeast Strains
}

\author{
Clarence S. Yah, Sunny E. Iyuke, Emmanuel I. Unuabonah, Odelia Pillay, \\ Chetty Vishanta and Samuel M. Tessa \\ School of Chemical and Metallurgical Engineering, \\ Faculty of Engineering and the Built Environment, University of the Witwatersrand, \\ Wits 2050 Johannesburg, South Africa
}

\begin{abstract}
Problem statement: Dilute sulphuric acid and enzymatic hydrolysis methods were used for sugar extraction. Xylose and glucose sugars were obtained from corn cobs. Approach: Acid hydrolysis of corn cobs gave higher amount of sugars than enzymatic hydrolysis. Results: The results showed that optimal temperature and time for sugar fermentation were approximately $25^{\circ} \mathrm{C}$ and $50 \mathrm{~h}$ by two yeast strains (S. cerevisiae and P. Stipitis) respectively. At 20 and $40^{\circ} \mathrm{C}$, less bioethanol was produced. Bioethanol produced at $25^{\circ} \mathrm{C}$ was $11.99 \mathrm{mg} \mathrm{mL}^{-1}$, while at 40 and $20^{\circ} \mathrm{C}$ were 2.50 and $6.40 \mathrm{mg} \mathrm{mL} \mathrm{m}^{-1}$ respectively. Conclusion/Recommendations: Data obtained revealed that xylose level decreased from 27.87-3.92 $\mathrm{mg} \mathrm{mL}^{-1}$ during the first $50 \mathrm{~h}$ of fermentation and complete metabolism of glucose was observed during this time. Xylose and bioethanol levels remained constant after $50 \mathrm{~h}$. Varying the temperature of the fermentation process improves the effective utilization of corn cobs sugars for bioethanol production can be achieved.
\end{abstract}

Key words: Bioethanol, corn cobs, optimization, fermentation, hydrolysis

\section{INTRODUCTION}

In an attempt to maximize waste product into useful material, this article seeks to determine the optimal temperature for large scale bioethanol production from corn cobs. Corn cob, a waste product of corn contains large amount of sugars that can be further utilized to produce various compounds (Cao et al., 1996; Adesanya and Raheem, 2009). The bioconversion of lignocellulosics to biofuel from cheap non-edible materials such as corn cob for renewal energy is imperative. Thus, by varying temperature conditions during the fermentation process, maximum productivity of biofuel on an industrial scale can be optimized.

In the brewing industry, production of biofuel is carried out by the fermentation of starchy materials, in which case, sugars are converted into bioethanol with carbon dioxide and water (Hongguang, 2006) as byproducts. For waste plant materials to be valuable, it must be converted to fuel as a sustainable substitute to fossil fuel. Therefore, there is a need for renewable energy resources from non-edible agricultural sources such as corn cob to replace fossil forms. This is because gas emissions from plant feedstock fuel are less than those emitted by fossil forms and thus beneficial to the environment and global warming (Demirbas, 2005; Hongguang, 2006). Bioethanol produced from corn uses only a small part of the plant material, whereby only the starch from the kernel is transformed into bioethanol (Cao et al., 1996). Several research studies have been carried out on the production of bioethanol from corn cobs through simultaneous saccharification and fermentation of lignocellulosic agricultural wastes by Kluyveromyces marxianus 6556 (Zhang et al., 2009), using Aspergillus niger and Saccharomyces cerevisae in simultaneous saccharification and fermentation (Zakpaa et al., 2009) and from Lignocellulosic Biomass (Kumar et al., 2009).

Corn however, is a main staple food in South Africa with an annual production of 8.04 million tons (Adesanya and Raheem, 2009). The cobs produced from corn are mainly used as manure for agricultural production. According to the report of Latif and Rajoka (2001), modern biotechnology allows the use of such lignocellulosic substrates as corn cobs in the production of chemicals and fuels, utilizing microorganisms. It has been shown that when corn is used for bioethanol

Corresponding Author: Clarence S. Yah, School of Chemical and Metallurgical Engineering,

Faculty of Engineering and the Built Environment, University of the Witwatersrand,

Wits 2050 Johannesburg, South Africa Tel.: 0117177594 Fax: 0117177599 
production at higher temperatures, yeast cells die resulting in a decrease in alcohol yield when the pulp is concentrated, while optimal temperature for maximum productivity occurs at $32^{\circ} \mathrm{C}$ (Araque et al., 2008). It is therefore, necessary to select the optimum temperature at which yeast strains can ferment the sugars from lignocellulosic material.

The Simultaneous Saccharification and Fermentation (SSF) process has been identified as economically viable for the conversion of these substrates to fermentation products (Cao et al., 1996). Conversion of glucose and xylose to ethanol by coyeast strains has been successfully obtained by Taniguchi et al. (1997) using a respiratory deficient mutant of Saccharomyces cerevisiae and Pitchia stipitis. Pichia stipitis strains ferment xylose at a high capacity of $57 \mathrm{~g} \mathrm{~L}^{-1}$ than any other yeast, provided the $\mathrm{pH}$ is maintained at between 4.5 and 6 and temperature of $25-26^{\circ} \mathrm{C}$ (Jeffries et al., 2007). According to Jeffries et al. (2007), maximum yield of ethanol is obtained when a mixture of $S$. cerevisiae and $P$. stipitis are introduced into a medium containing both glucose and xylose. The amount of bioethanol produced therefore, depends on the optimal temperature which, invariably influence sugar utilization by yeast cells (Mwesigye and Barford, 1996).

Problem statement: From the above it is obvious several microorganisms have used in the production of bioethanol but non has utilized a combination of $S$. cerevisiae and $P$. stipitis in the production of bioethanol from corn cobs. This study, therefore, utilized an agricultural waste material (corn cobs) in the production of bioethanol as a cheap but effective alternative fuel source to power automobile. Furthermore, time and temperature in the bioethanol production process using the two yeast strains (S. cerevisiae and P. stipitis) were optimized.

\section{MATERIALS AND METHODS}

The chemicals and reagents used in the study were of analytical grade. The sugar extraction process from the corn cobs was according to Cao et al. (1996). The sugar analyses were determined using the HPLC (Agilent Technologies, Waldbronn, Germany). Two strains of yeast: $S$. cerevisiae and $P$. stipitis were used for the fermentation experiment and were obtained from the School of Molecular Biology, University of the Witwatersrand.

Approach: Methods used in the production of bioethanol in this study were the acid hydrolysis and the enzyme hydrolysis methods after the corn cob were steeped in ammonia hydroxide solution to release lignin from the cob. Both methods were compared to determine which gives better yield of fermentable sugars. The fermentable sugars were then treated with the yeast strains at different temperatures and time. This is to optimize the temperature and time in the use of both yeast strains in the production of bioethanol from corn cob.

Ammonia steeping: Twenty grams of milled corn cobs of particle size of $2 \mathrm{~mm}$ was mixed with $100 \mathrm{~mL} 2.9 \mathrm{M}$ $\mathrm{NH}_{4} \mathrm{OH}$ solution in a $250 \mathrm{~mL}$ Erlenmeyer flask. The mixture was then incubated in a shaker for $24 \mathrm{~h}$ at $30^{\circ} \mathrm{C}$. The content was then filtered using a $2 \mu \mathrm{m}$ filter paper into $250 \mathrm{~mL}$ Erlenmeyer flask. It was further rinsed twice using distilled water. The corn cobs were then dried at $30^{\circ} \mathrm{C}$ in an oven overnight.

Dilute acid hydrolysis: The dried corn cobs were then delignified by treating with $0.3 \mathrm{M} \mathrm{HCl}$ solution at $121^{\circ} \mathrm{C}$ for $1 \mathrm{~h}$. The amount of $\mathrm{HCl}$ added to dry biomass weight is in the ratio of $1: 10 \mathrm{w} / \mathrm{v} .0 .5 \mathrm{M} \mathrm{NaOH}$ was then used to neutralize the acidic hemicellulose hydrolyzate. The pre-treated cellulosic residue was then washed with distilled water to remove residual acid.

Enzymatic hydrolysis: In a $250 \mathrm{~mL}$ flask, $50 \mathrm{~mL}$ of water and $300 \mu \mathrm{L}$ of cellulase was added to the cellulosic residue to convert cellulose to fermentable sugars at $50^{\circ} \mathrm{C}$ for $48 \mathrm{~h}$ (Sun and Cheng, 2002).

Yeast culture: Each yeast strain was grown in cooled $25 \mathrm{~mL}$ broth Yeast Potato Dextrose (YPD) medium prepared by adding $1 \mathrm{~g}$ of yeast extract, $2 \mathrm{~g}$ of peptone powder and $2 \mathrm{~g}$ of glucose powder to $25 \mathrm{~mL}$ of distilled water and autoclaved at $121^{\circ} \mathrm{C}$ for $15 \mathrm{~min}$. The cultured medium was then placed in an incubator shaker at $220 \mathrm{rpm}$ for $18 \mathrm{~h}$.

Bioethanol fermentation: Twenty five $\mathrm{ml}$ each of hemicellulose hydrolyzate and cellulose hydrolyzate were mixed, inoculated in $500 \mu \mathrm{L}$ each of yeast medium and covered with cheese cloth to allow for proper gaseous exchange. The samples were then put into incubator shakers at different temperatures and shaken for $180 \mathrm{rpm}$. The sugar concentrations were then analysed with HPLC according to the method described by Duke and Henson (2008). In order to remove the yeast cells from the fermentation products, the cultured broth were sterilely filtered. The temperature was varied from $15-40^{\circ} \mathrm{C}$. The fermentation process was carried out according to Cao et al. (1996). 


\section{RESULTS}

In order to investigate the optimum temperature the acid and enzymatic hydrolysis were used to determine the amount of sugars produced. There was a significant difference $(p<0.001)$ of the sugars obtained from acid and enzymatic hydrolysis. The results showed that the acid hydrolysis produced 1.6 and $30.23 \mathrm{mg} \mathrm{mL}^{-1}$ of glucose and xylose sugars respectively while the enzymatic hydrolysis gave 0.12 and $5.7 \mathrm{mg} \mathrm{mL}^{-1}$ of glucose and xylose sugars respectively. This indicates that enzymatic hydrolysis produces fewer sugars than acid hydrolysis (Fig. 1). The fermentation process was repeated for the temperatures $20,25,30$ and $40^{\circ} \mathrm{C}$. During the fermentation process, the levels of glucose, xylose and bioethanol were measured after every $5 \mathrm{~h}$.

The result in Fig. 2 shows the concentration of glucose during the fermentation period. It was found that the level of sugar utilization by the yeast strains was faster at $25^{\circ} \mathrm{C}$ than at 20,30 and $40^{\circ} \mathrm{C}$. It took $25 \mathrm{~h}$ for the glucose to be completely metabolized at $25^{\circ} \mathrm{C}$, $50 \mathrm{~h}$ at 20 and $30^{\circ} \mathrm{C}$ respectively. It also took $63 \mathrm{~h}$ for the glucose to be metabolized by the yeast strains at $40^{\circ} \mathrm{C}$ (Fig. 2). The glucose concentrations for the temperatures $20,25,30$ and $40^{\circ} \mathrm{C}$ all dropped from $0.74-0 \mathrm{mg} \mathrm{mL}^{-1}$ at time $25 \mathrm{~h}\left(25^{\circ} \mathrm{C}\right), 50 \mathrm{~h}(20$ and $\left.30^{\circ} \mathrm{C}\right)$ and $63 \mathrm{~h}\left(40^{\circ} \mathrm{C}\right)$ (Fig. 2).

The results of xylose fermentation at varying temperatures are shown in Fig. 3. The results indicated that at $25^{\circ} \mathrm{C}$, the yeast strains utilize the xylose faster than at any other temperature. The utilization was poor at 20,30 and $40^{\circ} \mathrm{C}$ (Fig. 3). The xylose concentrations for the temperatures $20,25,30$ and $40^{\circ} \mathrm{C}$ all dropped from $29.77-11.99 \mathrm{mg} \mathrm{mL}^{-1}\left(20^{\circ} \mathrm{C}\right), 3.92 \mathrm{mg} \mathrm{mL}^{-1}$ $\left(25^{\circ} \mathrm{C}\right), 5.80 \mathrm{mg} \mathrm{mL}^{-1}\left(30^{\circ} \mathrm{C}\right)$ and $15.01 \mathrm{mg} \mathrm{mL}^{-1}$ $\left(40^{\circ} \mathrm{C}\right)$ respectively at time $50 \mathrm{~h}$ (Fig. 3$)$.

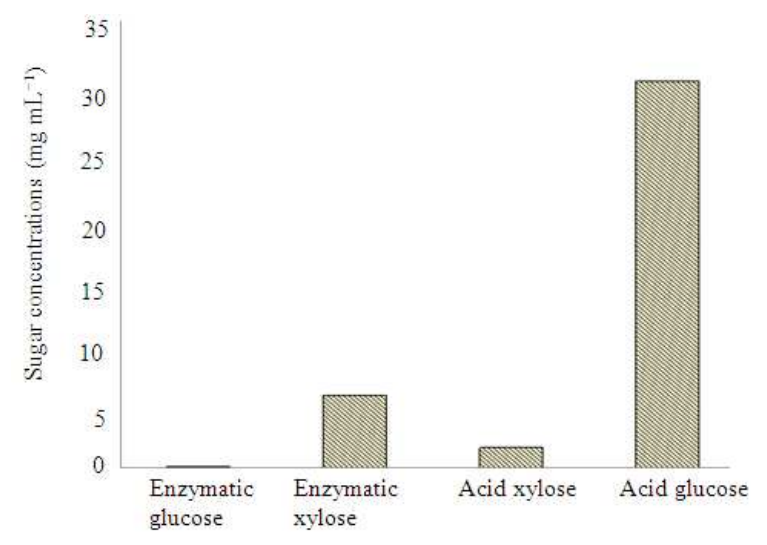

Fig. 1: The concentration of sugars produced from corn cobs using both acid and enzymatic hydrolysis
The result of the bioethanol concentration at the various temperatures is shown in Fig. 4. The two yeast cells were able to ferment the sugars at optimum temperature (Fig. 4).

The highest concentration of bioethanol produced from both sugars was $11.99 \mathrm{mg} \mathrm{mL}^{-1}$ at $25^{\circ} \mathrm{C}$. The lowest concentration of bioethanol produced was $2.47 \mathrm{mg} \mathrm{mL}$ at a temperature of $40^{\circ} \mathrm{C}$. At temperatures of 20 and $30^{\circ} \mathrm{C}$, the concentrations of bioethanol were found to be 6.40 and $11.08 \mathrm{mg} \mathrm{mL}^{-1}$ respectively (Fig. 4).

Figure 5 shows the production of bioethanol at $25^{\circ} \mathrm{C}$. The results showed that the concentrations of the sugars decreased while the concentration of bioethanol increased with respect to time. According to Jeffries et al. (2007) by using $S$. cerevisiae only, the glucose gets converted quickly (after about $12.5 \mathrm{~h}$ ), while the xylose takes approximately $48 \mathrm{~h}$ to be converted to bioethanol and other products. Therefore, the addition of $P$. stipitis yeast to $S$. cerevisiae enhanced the conversion rate of the sugars into bioethanol.

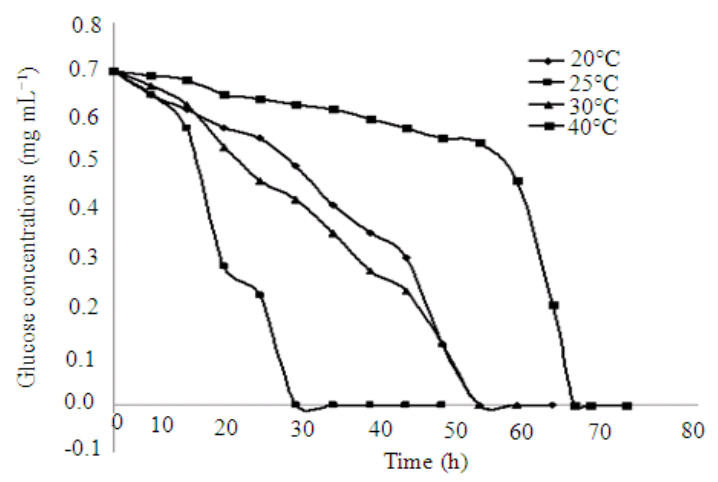

Fig. 2: The amount of Glucose fermentation from corn cob by $S$. cerevisiae and $P$. Stipitis

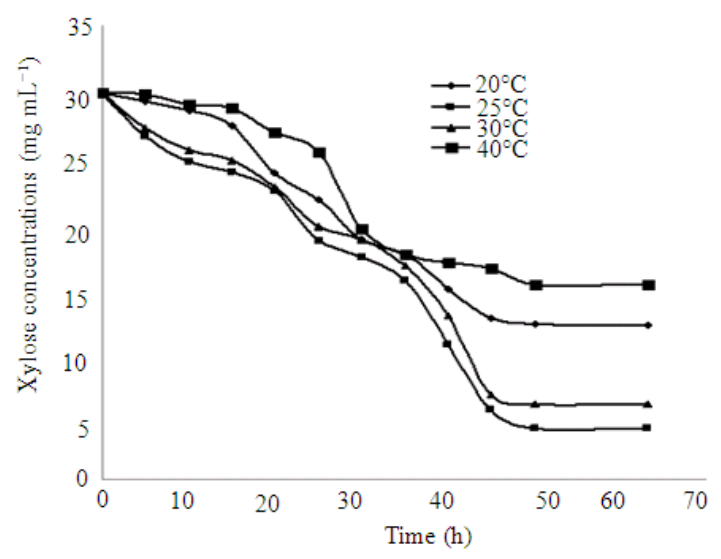

Fig. 3: The amount of Xylose fermentation from corn cob by $S$. cerevisiae and $P$. Stipitis 


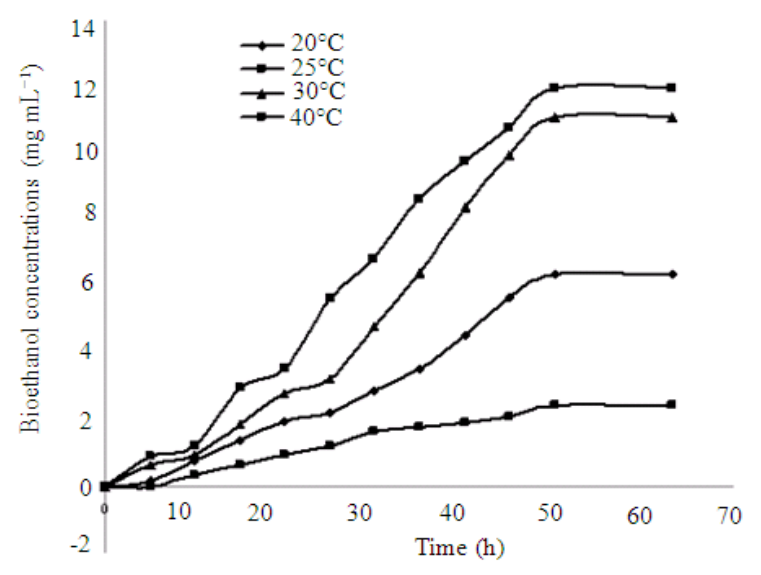

Fig. 4: The amount of bioethanol produced from glucose and xylose sugars

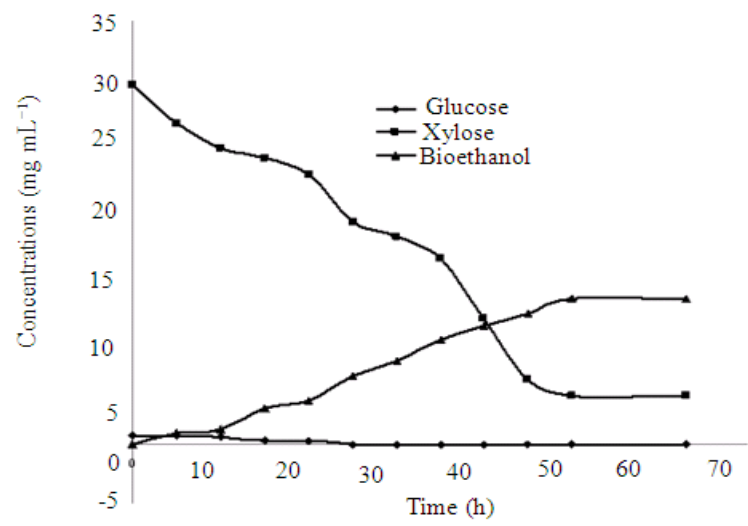

Fig. 5: Temperature optimization of bioethanol production from glucose and xylose sugars at $25^{\circ} \mathrm{C}$

Figure 5 shows that the concentrations of glucose and xylose decrease as the concentration of bioethanol increased to a constant concentration of $11.99 \mathrm{mg} \mathrm{mL}^{-1}$ at $25^{\circ} \mathrm{C}$. All of the glucose was used up. However, the final concentration of xylose was found to be $3.92 \mathrm{mg} \mathrm{mL}^{-1}$ after $50 \mathrm{~h}$.

\section{DISCUSSION}

The high concentration of xylose present after acid hydrolysis (Fig. 1), could be due to the fact that very small amount of lignin was removed during ammonia steeping. Similar observation has been made by Cao et al. (1996) and Kumar et al. (2009) where they found very high amounts of xylose produced during acid hydrolysis from hemicellulosic material. The analytical studies reveal glucose level of $1.62 \mathrm{mg} \mathrm{mL}^{-1}$ during acid hydrolysis and enzymatic level of $0.12 \mathrm{mg} \mathrm{mL}^{-1}$. The concentration of the sugar hydrolysates after acid hydrolysis was similar to previous reports by Latif and Rajoka (2001). The xylose fraction during acid hydrolysis was $30.23 \mathrm{mg} \mathrm{mL} \mathrm{mL}^{-1}$ as compared to $5.70 \mathrm{mg} \mathrm{mL}$ of enzymatic hydrolysis. This also follows similar findings by Deng et al. (2007) that cellulosic biomass can be easily be hydrolyzed with dilute acid to produce monomeric sugars. The high xylose production was due to the ammonia steeping process which stimulated the cellulosic materials to swell, therefore promoting the efficiency of the acid hydrolysis process. This finding confirm earlier reports by Cao et al. (1996) that after the ammonia steeping process the corn cob hemicellulosic fraction can easily be hydrolyzed by dilute acid as well as separated from the cellulosic fraction. Thus, acid hydrolysis of corn cobs after ammonia steeping gave better yield of fermentable sugar than the enzymatic method.

According to Fig. 2 and 3, the concentrations of xylose and glucose decreased with respect to and temperatures time for all temperatures (Cao et al., 1996). It can also be seen that between 25 and $30^{\circ} \mathrm{C}$, the sugars were used up faster than at 20 and $40^{\circ} \mathrm{C}$. It can be seen that at $25^{\circ} \mathrm{C}$, the glucose concentration reached $0 \mathrm{mg} \mathrm{mL}{ }^{-1}$ after $25 \mathrm{~h}$ and the concentration at $30^{\circ} \mathrm{C}$ reached $0 \mathrm{mg} \mathrm{mL}^{-1}$ after $50 \mathrm{~h}$. The reason for this is because $S$. cerevisiae and $P$. stipitis are known to convert sugars into bioethanol at temperature range of 25 and $30^{\circ} \mathrm{C}$ (Van Vleet and Jeffries, 2009).

Figure 3 shows the concentration of xylose which also decreased with respect to time for all temperatures correlating with the reported by Cao et al. (1996). The xylose was converted faster at $25^{\circ} \mathrm{C}$ than at $30^{\circ} \mathrm{C}$. At this temperature the xylose concentration was found to be approximately $3.92 \mathrm{mg} \mathrm{mL}^{-1}$ after $50 \mathrm{~h}$. This could be due to the fact that $P$. stipitis converts xylose into bioethanol at an optimum temperature of $25^{\circ} \mathrm{C}$ (Jeffries et al., 2007). Theoretically, $100 \mathrm{~g}$ of glucose should produce approximately $50.4 \mathrm{~g}$ of bioethanol and $48.8 \mathrm{~g}$ of carbon dioxide. However, practically, microorganisms use up most of the glucose sugar for growth. Thus, the actual yield of bioethanol is less than $100 \%$ (Araque et al., 2008). From literature it has been shown that the operating temperatures are less than expected because yeast cells performance may have been inhibited by other inherent components within in the fermentation process (Galitsky et al., 2003; Sinha et al., 2006; Deng et al., 2007).

In Fig. 4, the concentration of the bioethanol was found to increase with respect to time for all temperatures which supports results obtained in literature (Cao et al 1996; Demirbas, 2005). The highest amount 
of bioethanol was produced at $25^{\circ} \mathrm{C}$ and was found to be $11.99 \mathrm{mg} \mathrm{mL}^{-1}$ at approximately $50 \mathrm{~h}$ of metabolism. The second highest concentration of bioethanol at $30^{\circ} \mathrm{C}$ was found to be approximately $11.08 \mathrm{mg} \mathrm{mL}^{-1}$ after $50 \mathrm{~h}$. At $40^{\circ} \mathrm{C}$, there was a poor conversion of sugars and therefore the bioethanol produced after $50 \mathrm{~h}$ was approximately $2.47 \mathrm{mg} \mathrm{mL}^{-1}$. This suggests that $25^{\circ} \mathrm{C}$ and $50 \mathrm{~h}$ are the optimum temperature and time for the production of bioethanol using a combination of $S$. cerevisiae and $P$. stipitis yeast strains.

During fermentation at high temperatures, Araque et al. (2008) observed that some adaptable resistance factors from the yeast cells can be generated that can give rise to the difference in ethanol yield. Similar effects were reported previously by AbdelFattah et al. (2000). Initial rapid decrease of sugar observed in Fig. 4 was due to a rapid multiplication of yeast cells and the rapid conversion of the sugars to alcohol via the glucose metabolism (Gibson et al., 2008). Generally there was a positive correlation between the sugar reduction of the fermenting medium and a concomitant increase in the ethanol production (Fig. 5). Figure 5 shows the optimum temperature of bioethanol production from glucose and xylose at $25^{\circ} \mathrm{C}$ where the highest amount of ethanol was produced. Generally, during fermentation, monomeric sugars are metabolized faster than di-, tri- and polymeric sugars. There was a significant difference $(\mathrm{p}<0.001)$ in ethanol production when the fermentation process approached $50 \mathrm{~h}$ after that the concentrations of xylose and bioethanol remain constant. This is due to the yeast cells dying and hence after this point no fermentation was really successful.

\section{CONCLUSION}

Varying the temperature of the fermentation of corn cobs sugars has an impact on bioethanol production. It was observed that the concentration of sugars (glucose and xylose) after enzymatic hydrolysis was less than that of the acid hydrolysis. The results showed that the combination of ammonia steeping followed by dilute acid hydrolysis gave high amount of sugars. The glucose and xylose concentrations were found to decrease with respect to time whilst that of the bioethanol was found to increase with respect to time. The optimum time and temperature for bioethanol production $S$. cerevisiae and $P$. stipitis strains were found to be at $50 \mathrm{~h}$ and $25^{\circ} \mathrm{C}$ respectively.

\section{ACKNOWLEDGEMENT}

The authors acknowledge the financial support from the National Research Fund (NRF) and SA-chair
Program, APV Invensys, equipment donation from Falcon Engineering (Pty) Ltd, South Africa, raw material supply from SABMiller of Alrode, South Africa and moral and technical support from John Cluett of IBD Africa Section and Anton Erasmus of SABMiller, South Africa.

\section{REFERENCES}

Abdel-Fattah, W., M. Fadil, I. Banet, 2000. Isolation of thermotolerant ethanologenic yeast and use of selected strains in industrial scale fermentation in an Egyptian distillery. Biotechnol. Bioeng., 68: 531-532. PMID: 10797239

Adesanya, D.A. and A.A. Raheem, 2009. Development of corn cob ash blended cement. Const. Build. Mater., 23: 347-352. DOI: 10.1016/j.conbuildmat.2007.11.013

Araque, E., C. Parra, M. Rodriguez, J. Freer and J. Baeza, 2008. Selection of thermotolerant yeast strains Saccharomyces cerevisiae for bioethanol production. Enzyme Microb. Technol., 43: 120-123. DOI: 10.1016/j.enzmictec.2008.02.007

Cao, N.J., M.S. Krishnan, J.X. Du, C.S. Gong and N.W.Y. Ho et al., 1996. Ethanol production from corn cob pretreated by the ammonia steeping process using genetically engineered yeast. Biotechnol. Lett., 118: 1013-1018. DOI: 10.1007/BF00129723

Demirbas, A., 2005. Bioethanol from cellulosic materials: A renewable motor fuel from biomass. Energy Sour., 27: 327-337. DOI: 10.1080/00908310390266643

Deng, L., Y. Wang, Y. Zhang and M.A. Runyu, 2007. The enhancement of ammonia pretreatment on the fermentation of rice straw hydrolysate to xylitol. J. Food Biochem., 31: 195-205. DOI: 10.1111/j.1745-4514.2007.00102

Duke, S.H. and C.A. Henson, 2008. A comparison of barley malt quality measurements and malt sugar concentrations. J. Am. Soc. Brew. Chem., 66: 151-161.

http://cat.inist.fr/?aModele $=$ afficheN\&cpsidt $=2059$ 9512

Galitsky, C., N. Martin, E. Worrell and B. Lehman, 2003. Energy efficiency improvement and cost saving opportunities for breweries. An ENERGY STAR ${ }^{\circledR}$ Guide for Energy and Plant Managers, Ernest Orlando Lawrence Berkeley National Laboratory, University of California Berkeley, CA 94720, pp: 5-74. http://ies.lbl.gov/iespubs/50934.pdf 
Gibson, B.R., C.A. Boulton, W.G. Box, N.S. Graham and S.J. Lawrence et al., 2008. Carbohydrate utilization and the lager yeast transcriptome during brewery fermentation. Yeast, 25: 549-562. PMID: 18668645

Hongguang, W., 2006. Biomass energy development welcoming bright prospects. Helmholtz Gemeinschaft. en.ce.cn/Insight/200703/02/t20070302_10560407.shtml

Jeffries, T.W., I.V. Grigoriev, J. Grimwood, J.M. Laplaza and A. Aerts, 2007. Genome sequence of the lignocelluloses-bioconverting and xylosefermenting yeast Pichia stipitis. Nat. Biotechol., 25: 319-326. DOI: $10.1038 /$ nbt1290

Kumar, S., S.P. Singh, I.M. Mishra and D.K. Adhikari, 2009. Recent Advances in production of bioethanol from lignocellulosic biomass. Chem. Eng. Technol., 32: 517-526. DOI: 10.1002/ceat.200800442

Latif, F. and B.I. Rajoka, 2001. Production of ethanol and xylitol from corn cobs by yeasts. Bioresour. Technol., 77: 57-63. DOI: 10.1016/S09608524(00)00134-6

Mwesigye, P. and J. Barford, 1996. Batch growth and transport kinetics of utilization of mixtures of sucrose and maltose by Saccharomyces cerevisiae. J. Ferment. Bioeng., 2: 101-108. DOI: 10.1016/0922-338X(96)85029-X

Sinha, B., P.K. Srakar, S.N. Ron and Bandyopadhyay, 2006. Yeast separation by ceramic membrane and flux recovery after chemical cleaning. Indian Chem. $\quad$ Engr., 48: 49-53 http://direct.bl.uk/bld/PlaceOrder.do?UIN=189110 $120 \&$ ETOC $=$ RN\&from $=$ searchengine
Sun, Y. and J. Cheng, 2002. Hydrolysis of lignocellulosic materials for ethanol production: A review. Bioresour. Technol., 83: 1-11. DOI: 10.1016/S0960-8524(01)00212-7

Taniguchi, M., T. Tohma and M. Fujii, 1997. Ethanol production from a mixture of glucose and xylose by co-culture of Pitchia stipitis and a respiratoryde®cient mutant of Saccharomyces cerevisiae. J. Ferment. Bioeng., 83: 364-370.

Van Vleet, J.H. and T.W. Jeffries, 2009. Yeast metabolic engineering for hemicellulosic ethanol Production. Curr. Opin. Biotechnol., 20: 300-306. PMID: 19545992

Zakpaa, H.D., E.E. Mak-Mensah and F.S. Johnson, 2009. Production of bio-ethanol from corncobs using Aspergillus niger and Saccharomyces cerevisae in simultaneous saccharification and fermentation. Afr. J. Biotechnol., 8: 3018-3022. http://www.academicjournals.org/AJB/PDF/pdf200 9/6\%20Jul/Zakpaa\%20et\%20al.pdf

Zhang, M., P. Shukla, M. Ayyachamy, K. Permaul and S. Singh, 2009. Improved bioethanol production through simultaneous saccharification and fermentation of lignocellulosic agricultural wastes by Kluyveromyces marxianus 6556. World J. Microbiol. Biotechnol., 26: 1041-1046. DOI: 10.1007/s11274-009-0267-0 